\title{
Diagnosis of sex in preimplantation embryos by fluorescent in situ hybridisation
}

\author{
Darren K Griffin, Leeanda J Wilton, \\ Alan H Handyside, Glenn H G Atkinson, \\ Robert M L Winston, Joy D A Delhanty
}

\section{Department of Genetics and Biometry, University College London, London NW1 2HE \\ D K Griffin, research fellow J D A Delhanty, reader in genetics \\ Institute of Zoology, Zoological Society of London, London NW1 4RY}

L J Wilton, research fellow

Institute of Obstetrics and Gynaecology, Royal Postgraduate Medical School, Hammersmith Hospital, London W12 ONN

A H Handyside, senior lecturer

G H G Atkinson, registrar R M L Winston, professor of fertility studies

Correspondence to:

Dr Delhanty.

BMF 1993;306:1382
The aim of prenatal genetic diagnosis is to give parents the option of terminating affected pregnancies. For most $\mathrm{X}$ linked conditions specific diagnosis is not possible and the only option is induced abortion of all male fetuses, of which half would be unaffected. An alternative is offered by preimplantation diagnosis of sex in embryos obtained by in vitro fertilisation and selective transfer of female embryos. The sex of preimplantation embryos has been determined by amplification of a DNA fragment specific to the Y chromosome by the polymerase chain reaction after biopsy of the embryo at the eight cell stage. ${ }^{1}$ Live births of female infants have followed this procedure, testifying to its safety. ${ }^{2}$ Misdiagnosis is, however, possible because of contamination, failure of amplification, or the sampling of anuclear cytoplasmic fragments. ${ }^{3} \mathrm{We}$ report the application of dual colour fluorescent in situ hybridisation for sexing interphase nuclei of three day old human preimplantation embryos.

\section{Methods and results}

Six couples at risk of transmitting an $\mathrm{X}$ linked disorder underwent seven cycles of routine in vitro fertilisation treatment, and biopsy specimens of one or two cells were taken from embryos at the $6-10$ cell stage early on the third day after fertilisation. ${ }^{1}$ The cells were pretreated with hypotonic solution, fixed, and spread on to glass slides as described previously. ${ }^{4}$ Dual fluorescent in situ hybridisation was performed by dehydrating the specimens, treating them with ribonuclease $A$ and proteinase $K$, and hybridising them with biotinylated probe $\mathrm{pBamX} 7$ (specific for the $\mathrm{X}$ chromosome) and digoxigenin labelled probes pHY2.1 and cY98 (specific for the Y chromosome). The two hour hybridisation was followed by post-hybridisation washes. ${ }^{4}$

The biotin and digoxigenin labels were detected with fluorescein isothiocyanate (green fluorochrome) conjugated with avidin and tetramethyl rhodamine isothiocyanate (red fluorochrome) conjugated with anti-digoxigenin antibody. Both were applied simultaneously in a TRIS based buffer containing a fluorochrome blocking reagent. Slides were mounted in an anti-fade medium with the blue fluorescent DNA counterstain diamidinophenylindole and then viewed for blue, green, and red fluorescence separately. This was adapted from our earlier dual fluorescent in situ hybridisation technique ${ }^{4}$ to allow the whole procedure to be performed in one working day. Nuclei were located by means of the counterstain. Cells, and hence embryos, were diagnosed as female if two green (X chromosome) and no red ( $\mathrm{Y}$ chromosome) signals could be seen and as male if one or more red signals was seen. Control lymphocyte material gave $95-100 \%$ of the expected number of signals from interphase nuclei, and no male nucleus was ever identified as female.

A positive female diagnosis on a single embryonic cell was considered to be sufficient to allow transfer to proceed. Selective transfer of female embryos took place late on the third day after fertilisation. In six of the cycles of treatment two female embryos were transferred, while in the seventh only one embryo was diagnosed as female and thus transferred (table). Two pregnancies ensued, of which one resulted in the birth of a normal female infant. The birth weight was $3550 \mathrm{~g}$, Apgar scores were 8 at five minutes and 9 at 10 minutes, and the infant was progressing well at 3 months of age. Failure to obtain a result for a total of five embryos in case 4 was due to the poor quality of the embryos and the removal of cells without clearly visible nuclei in some cases. The sex of the embryos which were diagnosed as male, and hence not transferred, was independently assessed and the aborted embryo in case 1 was confirmed as female.

\section{Comment}

We have shown that sexing of biopsy specimens of single cells by dual colour fluorescent in situ hybridisation is an effective strategy for screening embryos in families with $\mathrm{X}$ linked disorders. This is an improvement on the use of the polymerase chain reaction and on other in situ hybridisation sexing techniques as it requires simultaneous detection of $\mathrm{X}$ and $\mathrm{Y}$ chromosomes, each in a different colour, and thus minimises the risk of misdiagnosis.

We thank Eleni Kontogianni for diagnosing the sex of rejected embryos from cases 1-3 by the polymerase chain reaction, and Karin Dawson and all the staff of the infertility clinics at the Hammersmith and Royal Masonic hospitals. This work was approved by the research ethics committee of the Royal Postgraduate Medical School, Hammersmith Hospital, and the Interim Licensing Authority for Human In Vitro Fertilisation and Embryology. DKG was supported by a Medical Research Council grant (No G9107290CB).

1 Handyside AH, Penketh RJA, Winston RML, Pattison JK Delhanty JDA, Tuddenham EGD. Biopsy of human preimplantation embryos and sexing by DNA amplification. Lancet 1989; i:347-9.

2 Handyside AH, Kontogianni EH, Hardy K, Winston RML. Pregnancies from biopsied human preimplantation embryos sexed by Y-specific DNA amplification. Nature 1990;344:768-70.

3 Handyside AH, Delhanty JDA. Cleavage stage biopsy of human embryos and diagnosis of X-linked recessive disease. In: Edwards RG, ed. Preimplantation diagnosis of human genetic disease. Cambridge: Cambridge University Press, 1993:239-70.

4 Griffin DK, Wilton LJ, Handyside AH, Winston RML, Delhanty JDA. Dual fluorescent in situ hybridisation for the simultaneous detection of $X$ and $Y$ chromosome specific probes for the sexing of human preimplantation embryonic nuclei. Hum Genet 1992;89:18-22.

(Accepted 9 March 1993)

Diagnosis of sex of embryos at risk of carrying $X$ linked disorders by fluorescent in situ hybridisation

\begin{tabular}{|c|c|c|c|c|c|c|c|c|c|}
\hline \multirow{2}{*}{$\begin{array}{l}\text { Case } \\
\text { No }\end{array}$} & \multirow[b]{2}{*}{ Disorder } & \multirow{2}{*}{$\begin{array}{c}\text { Maternal age } \\
\text { (years) }\end{array}$} & \multirow{2}{*}{$\begin{array}{l}\text { No of } \\
\text { embryos } \\
\text { biopsied }\end{array}$} & \multicolumn{4}{|c|}{ Diagnosis of sex } & \multirow{2}{*}{$\begin{array}{c}\text { No of } \\
\text { embryos } \\
\text { transferred }\end{array}$} & \multirow{2}{*}{$\begin{array}{l}\text { Outcome of } \\
\text { pregnancy }\end{array}$} \\
\hline & & & & Female & Male & Unknown & Other & & \\
\hline 1 & Wiskott-Aldrich syndrome & 37 & 6 & 4 & 1 & 0 & $1^{\star}$ & 2 & Miscarriage in first trimester \\
\hline 2 & $\mathrm{X}$ linked myotubular myopthy & 31 & 7 & 4 & 3 & 0 & 0 & 2 & $\begin{array}{l}\text { Live birth of normal female } \\
\text { infant }\end{array}$ \\
\hline 3 & \multirow{4}{*}{$\begin{array}{l}\text { Adrenoleukodystrophy } \\
\text { X linked mental retardation } \\
\text { (non-fragile X type) } \\
\text { X linked mental retardation } \\
\text { (non-fragile X type) } \\
\text { Duchenne fype muscular }\end{array}$} & 35 & 8 & 3 & 3 & 1 & $1+$ & 2 & None \\
\hline \multirow[t]{3}{*}{4} & & 38 & 5 & 1 & 1 & 3 & $0_{0}^{0}$ & 1 & None \\
\hline & & & 4 & 2 & 0 & 2 & 0 & 2 & None \\
\hline & & 41 & 5 & 2 & 0 & 2 & $1^{\star}$ & 2 & None \\
\hline 6 & $\begin{array}{l}\text { Duchenne type muscular } \\
\text { dystrophy }\end{array}$ & 29 & 2 & 2 & 0 & 0 & 0 & 2 & None \\
\hline
\end{tabular}

^Apparently XO.

†Apparently XXX (one cell). 